Forthcoming in Routledge Companion to the Frankfurt School, ed. by E. Hammer, A. Honneth, and P. Gordon. London (etc.): Routledge, 2018.

\title{
Critical Theory and Social Pathology
}

Fabian Freyenhagen (University of Essex)

What is distinctive about Frankfurt School Critical Theory (FSCT)? One prominent answer has been that a particular conception of social pathology is constitutive of and unique to this tradition. This Chapter presents an analysis of the idea of social pathology and its role in FSCT. It suggests that this idea can, indeed, set FSCT apart from mainstream liberal approaches, but also notes the challenges involved in doing so and urges proponents of FSCT to return to something more like its original, interdisciplinary program.

The Chapter is structured as follows: I begin with a section on the idea of social pathology in general; then I investigate the claim that there is a specific FSCT conception of it; and, finally, I discuss two case studies. Throughout these sections, I gradually build a list of possible general characteristics and FSCT specifications of the idea of social pathology, and conclude by reviewing that list in its entirety.

\section{The idea of social pathology}

Do societies make us ill? Are societies themselves ill? For many centuries philosophers and social theorists answered these questions in the affirmative - for example, Plato spoke of democracies as being "feverish", Marx claimed that to labor under capitalist conditions "mortifies the flesh and ruins the mind," and Durkheim suggested that we could see how ill a community was by the kind and number of suicides its members committed. Similarly, in political and everyday discourse, medical metaphors are applied at the social level - be it the $19^{\text {th }}$ century claim of the Ottoman empire as "the sick man of Europe", or the more recent use 
of the same metaphor for Greece in the context of the sovereign debt crisis. After the 2011 riots, UK's then prime minister claimed that "pockets of our society are frankly sick." More recently, influential French economist Piketty described the Brexit referendum result as "a pathological response to a very real sense of abandonment." The mainstream press is peppered with similar observations. Already ten years ago, England's The Guardian bemoaned "a pervasively pornographic desire to see other people's raw emotion and hurt" as a "social pathology". In 2016, Germany's Die Zeit invoked the "social-pathological traits" of recent politics as having disinhibited aggression and resentment. Claims of this form are also found in contemporary social sciences, particularly in medical sociology and public health economics. For example, social epidemiologists Wilkinson and Pickett argued in an influential study that unequal societies make its members more ill than equal ones (2009); and political scientist Mounk recently described contemporary democracies as ill to the New York Times (see also Foa and Mounk 2016).

In sum, the idea of social pathology is highly evocative, features ubiquitously in contemporary discourses and has a long pedigree. However, it also is relatively ill-defined and beset by controversies. It is relatively ill-defined, first, because there is no consistent use as to whether it refers to the claim that society makes individuals ill or the claim that society itself is ill (possibly irrespective of the illness of individuals) or to both claims at once. Moreover, the notion of illness or pathology is often left vague. Sometimes, those who speak of social pathology simply take medical categories of pathology at face value and use these categories for advancing their claims (say, Stuckler and Baisu's argument in their 2013 study to the effect that IMF-imposed austerity in Thailand led to excess deaths from infectious diseases). Sometimes, the categories of illness and pathology are stretched beyond their medical context, but still understood as broadly to do with individual flourishing or lack of flourishing (for example, when Honneth speaks of social pathology in terms of detriments to self-realization; 
see below). At other times, talk of illness or pathology is perhaps merely metaphorical (as probably in the case of Mounk above).

There are also several reasons why the idea of social pathology is beset by controversies. Some object that it rests on an illicit analogy between society and an organism. Others point to an ugly history of abuse of the idea. Notoriously, Nazi propaganda portrayed the Jews as a pathogen in European society and used the rhetoric of social pathology to pursue a policy of extermination. This in turn points towards a further objection, which alleges that invoking this idea is more a reflection of antecedent ideological commitment than of good evidence and reasoning. Indeed, one might argue that the notion is so vague that it lends itself to pushing through policies that do not work. Moreover, one might also object to the status claimed for theorists of social pathologies and the status assigned to those (purportedly) affected by them: What legitimates one to be a doctor of society? And is social pathology talk not rendering those affected into passive victims, into "patients"?

These considerations raise a key question: can the idea of social pathology be fruitfully and legitimately used by FSCT? This tradition understands itself as an emancipatory project, and stands opposed to anti-Semitism and ideological obfuscation. It is meant to be particularly self-reflective and self-critical, including about the role it assigns to theorists, and to be alert to the lessons learnt from history. Is the idea of social pathology too tainted to be deployed by FSCT?

As a first step in answering this question, it will help to characterize this idea more precisely and to consider what, if anything, speaks for using it. (I will have much less to say about the legitimacy of its use, although later sections will at least delineate some of the challenges that would need to be addressed.) While the notion is relatively ill-defined, one characteristic is generally agreed: the social phenomena described by the idea of social pathology tend to be dynamic social processes, which, if not stopped or reversed, will lead to 
an increased deterioration of the situation - just as with an infection of the body. Indeed, there is a further parallel: as in physical pathologies, the social phenomena in question often involve a downward spiral whereby an initially well-suited response is progressively leading to a worsening of the situation. For an example of this from physical health, consider the effect of high blood pressure on arteries: the body reacts in a way that is, initially, well-adapted (the walls of the arteries thicken to withstand the higher blood pressure) but eventually fatal. Similarly, an initial response to high crime levels (such as more police presence) might well be legitimate, but trigger a downward spiral of violence and mutual alienation between local communities and the police. This points to an advantage of using the idea of social pathology: the vicious circles in question might be harder to capture adequately in other normative vocabulary or with other social models.

It also points to a second characteristic. The idea of social pathology is normally conceptualized as ordered by ethical criteria, here understood as differentiated from moral criteria. To clarify: There are various ways to relate ethics and morality, and various ways to understand each. One way of relating the two is to understand them as a contrast, whereby ethics has to do with the good and flourishing (and the bad and lack of flourishing), and morality has to do with justice and the right (and injustice and the wrong). In that way, the idea of social pathology is (part of) the other of justice; it presents a different normative vocabulary and register.

We will see below that this second characteristic is not universally adhered to by more recent proponents of FSCT, but for now it is useful to hold onto it. Notably, this second characteristic marks a difference between those who use the idea of social pathology and adherents of the dominant paradigm of contemporary political philosophy. For the past halfcentury or so, the dominant paradigm in political philosophy has operated within a particular normative register, which for our purposes here we can call the justice framework. Two features 
of that framework have effectively excluded the idea of social pathology from serious consideration:

- Priority of the right over the good: Political philosophy, on this approach, aims to articulate principles of justice valid for a pluralistic society in which citizens may have widely divergent conceptions of the good life. Success in this project is understood to require neutrality regarding these divergent conceptions. This starting point and principle of demarcation is then combined with a background assumption, viz., that social pathology presupposes an intrinsically contentious conception of the good. With these pieces in place, the idea of social pathology is excluded from the start.

- Relation to social sciences: The dominant contemporary approach in political philosophy understands its role as a form of normative theorizing that is fundamentally different from empirical social science. For many, this reflects a commitment to "ideal theory", according to which the principal task of political philosophy is the formulation of principles for a just society; empirical social science (on this picture) enters in primarily when it comes to applying the principles. Insofar as the idea of social pathology is intertwined with empirical questions and research, it has not found an easy place within this paradigm.

While these two features explain why the idea of social pathology does not feature in the dominant justice framework, they do not suffice to justify this lacuna. Just the opposite: this lacuna is, arguably, a missed opportunity. This is so for three reasons.

First, since the idea of social pathology is widespread in social discourse but absent from mainstream political philosophy, there is a deep disconnect which limits the ability of political philosophers to engage with broader socio-political discourse. This is particularly problematic if the idea of social pathology is ineliminable from critical reflection on society. This is not the place to argue systematically for this claim. Prima facie support for the ineliminability claim can be found both in the historical longevity and current ubiquity of the 
idea, together with the fact that it is applied across the political spectrum and around the world, and by lay persons and (social) scientists alike. Moreover, the model of organic unity is such a fundamental schema for understanding complexity that its application to social reality may well be inevitable.

At the same time, the justice framework is not well-suited to bring the full range of social phenomena properly into view - for example because individuals affected by the social ills do not even think of themselves as free and equal citizens making justice claims on each other (while this self-conception of citizens is a central presupposition of most variants of the dominant justice framework). Even where the dysfunctionality of current societies is admitted - say when it comes to climate change - this is shoehorned into the justice framework and the real phenomena are pushed in the background while theoretical problems take center stage. To stick with the example, instead of direct critical scrutiny of how climate change is intertwined with a particular economic system, the focus of those working in the dominant framework tends to be on theoretical conundrums, such as whether we can have obligations to future generations in the face of the "non-identity problem" (that is, the problem that each of the policy choices would lead to the existence of different populations of future individuals, meaning that there is no stable comparison class of people who would be affected). Arguably, the dominant justice framework, at best, diverts attention from social problems and, at worst, obfuscates them (see Geuss 2008; Finlayson 2015).

Moreover, the sharp division between normative political theorizing and empirical research has the unfortunate consequence that the resulting theories are not informed by important evidence being amassed by social scientists, such as in support of the thesis that "austerity kills" (Stuckler and Basu 2013). At the same time, this evidence and the way it has been collected is left unscrutinized by (political) philosophers, despite the fact that political dimensions are, often, clearly at play. To give just one other example: the way conditions and 
behavior are classified as mental disorder is not a normatively or politically neutral matter, and liberal theories which simply appeal to such classifications overlook the normative substance they are importing into their theories and, as a result, do not submit this substance to the critical scrutiny it deserves (Freyenhagen \& O’Shea 2013).

FSCT seems well-equipped to avoid these pitfalls, and thus harness the fruitfulness of the idea of social pathology. FSCT does not rule out ethical concerns from the start, but (traditionally) operates with a broader normative framework than the justice framework. It takes up the normative vocabulary of social struggles - not uncritically, to be sure, but in a way that need not imply a deep disconnect with broader socio-political discourse(s). And it does not conceive of itself as sharply divided from the social sciences, but as interwoven with them, both by drawing on them and by critically scrutinizing them.

It now is clearer why the idea of social pathology might be attractive to FSCT. More needs to be said about how this idea can be legitimate, but at least we have begun to see its fruitfulness in the face of certain social problems and vis-à-vis one other approach, the justice framework dominant in much of liberal political philosophy.

\section{A distinctive conception?}

In an influential paper, Honneth ascribes a particular conception of social pathology to (early) FSCT and claims that it is constitutive of its approach. He makes the general point that the idea of social pathology operates in an ethical register, in contrast to the dominant liberal concern with moral categories like justice (the second characteristic noted above). He then presents three fundamental specifications as constitutive and distinctive of (early) FSCT's use of this idea (none of which relate directly to the first general characteristics noted above, to which I return again in the second case study.) 
First, FSCT is unique in combining the idea of social pathology with "the concept of socially efficacious reason.” (Honneth 2008: 784) Following Hegel, the idea is that a social pathology is given whenever a society falls short of the "'objectively' already possible rationality." (Honneth 2008: 786) In contrast, "a successful form of society is only possible by maintaining at the highest level the appropriate standard of rationality." (Honneth 2008: 786) Thus, both the notion of social pathology and its contrast (what we might call "social health") are tied here to a particular conception of rationality. To say that society is ill or makes its members ill is to ascribe a deficit in rationality to society.

The idea of socially efficacious reason deserves explication. The basic thought is that human practices and institutions are tied up with rationality in various ways. In particular, they rely on norms to operate. In other words, they are not merely causal mechanisms, but operate on the basis of rules and values (however implicit or uncodified these may be). These encapsulate or provide the point of the practices and institutions. For example, the point of the health care system is to diagnose and treat disease and injuries; the point of primary schooling is to educate young children in a way that allows them to acquire basic skills (like literacy), which are crucial for them to function as free and equal citizens and pursue their own conception of the good. A practice and institution can fail to realize its in-build norms, either to some extent or perhaps even completely. For example, if a health care system became too dominated by the pursuit of profit at the expense of diagnosing and treating disease and injuries, it would thereby be a pathological case of a health care system: it would be irrational in the sense of failing to realize the norms to which it aspires. It might be helpful to note that what a practice and institution aspires to (and its norms more generally), can change over time or differ between societies (perhaps if the marketization of health care advances sufficiently, its norms simply will become commercial ones). This makes it difficult to distinguish between cases where a practice is not living up to its norm and cases where the underlying norm has changed. 
Socially efficacious reason will normally not be timeless and universal, but tied to a particular socio-historical context. However, some theorists within this Hegelian tradition are also committed to a historical progress story. The development of human practices and institutions over time is then understood not as a mere succession (like in a morphing sequence), but as representing improvements along one or several dimensions (like becoming more inclusive or increasingly governed by democratic will-formation).

There is clear evidence that FSCT from its inception has subscribed to a broadly Hegelian conception of reason, and criticized society for rationality deficits. Consider Horkheimer's seminal paper "Traditional and Critical Theory" (1937). In it, Horkheimer clearly confirms a conception of reason as socially efficacious. Notably, he writes: "The collaboration between human beings in society is the mode of existence of their reason, the way in which they apply their powers and confirm their essence." (1972: 204; translation amended). He continues by noting that the potential of reason to be fully and truly socially efficacious remains unrealized. Contemporary society, as reason's current manifestation, is both in process and result - alienating for its members: "all its waste of labour power and human life, and [...] its wars and all its senseless wretchedness" testify to its rationality deficit and this "misery of the present" grounds FSCT's aim of a truly rational society (1972: 204 and 216-7; translation amended).

Second, according to Honneth, society's rationality deficit has one specific (ultimate) cause in the (early) FSCT tradition: capitalism. Put in medical language: capitalism is modern society's pathogen. Here Honneth emphasizes the influence of Lukács, according to whom "[m]echanized practical work and commodity exchange demand a form of perception in which all other humans appear as thing-like beings lacking sensation, so that social interaction is robbed of any attention to properties valuable in themselves." (2008: 799) Such a narrowing of perception implies a narrowing of rationality - to instrumental rationality in the service of self- 
interest - and leads to a variety of social ills (not least alienation and exploitation in the Marxian sense). Lukács' model - though perhaps not the specifics of the content - is then adopted by FSCT and applied to a variety of contexts. While Honneth does not explicitly say so, the social pathologies that capitalism causes reveal it to have structural deficits, such that - at least for the early FSCT - the only cure is to rid us of capitalism.

Third, Honneth argues that the idea of social pathology in FSCT is always conjoined with an account of the emancipatory interest in overcoming it. He credits Freud with a formative influence. In particular, two insights are taken from Freud: (a) deficits in rationality always find expression, however indirectly, in experiences of suffering; and (b) this suffering motivates, and can be alleviated only by, the search for the very aspects of rationality whose suppression led to the suffering in the first place.

Honneth suggests that there are obstacles to upholding each of these three FSCT specifications of the idea of social pathology. He claims that, if one wants to defend FSCT's idea of social pathology (as he does), then one needs to reconfigure each of them (2008: 808). In his own work, he has particularly reconfigured the second, generalizing the account of the causes to one about the structural organization of societies. Capitalism can be one aspect or example of such structures, but is not the only one. For example, Honneth (2014) describes "juridification" (such as excessive appeal to rights and the legal system in personal affairs, exemplified in films like Kramer vs Kramer) as a social pathology, but claims that it is a consequence of the normative structure of legal freedom, its own tendency to become onesided. In other words, something deficient in the idea of legal freedom is the cause of this particular pathology, not something in the capitalist structure of society. The decoupling from capitalism as (ultimate) cause of social pathology takes place already in Habermas's work (1987). There, juridification is a social pathology that can arise from the structural organization 
of societies, but it is not necessarily caused by capitalism (at least not directly, insofar as juridification can result from attempts to contain capitalism).

One question one might ask about Honneth's portrayal of the particular conception of social pathology in the FSCT tradition is whether the three specifications are really setting FSCT apart from all other approaches. One might think that many left-Hegelian or Marxist views could subscribe to a conception of social pathology in terms of rationality deficits of society that are caused by capitalism and lead to suffering of a kind that can only be overcome when these rationality deficits are overcome. Perhaps even right-Hegelian approaches to political matters could subscribe to this.

Another question would be whether Honneth (and others) made FSCT conceptions of social pathology less distinctive when modifying the original specifications. Earlier we saw that one key characteristic of the idea of social pathology is that it is understood as an ethical idea in contrast to justice as a moral idea. This characteristic at least set the FSCT conception apart from the dominant justice framework. Yet, both Habermas and (the later) Honneth have reduced that difference. Habermas's claims about social pathology boil down to claims about rationality deficits, but these can be specified further to include deficits in moral rationality and hence justice (I provide an example below). Similarly Honneth, particularly in Freedom's Right, conceptualizes social pathologies now as part of an account of justice - substantive justice, purportedly different from procedural justice accounts Honneth ascribes to Habermas and Rawls, but a justice account nonetheless.

In addition, starting with Habermas and continuing with Honneth, an integral part of the conception of social pathology has become the notion of the functional differentiation of society. In Habermas's work, this functional differentiation is conceptualized as one between system and lifeworld (1987). Honneth, on the other hand, takes up Hegel's tripartite division of the social world (family, civil society, and state) in a slightly modified form (for example, 
the first sphere comprises more than just the family) (see notably 2014). A healthy society is then conceptualized as one in which the different spheres each play their functional role, like different organs do in a body (the liver or family have a different function from the brain or state, and so on) and interact in the proper way (the liver or market economy does not poison the rest of the physical or social body). Social pathology as rationality deficit is here understood as either a malfunction of a sphere or one sphere taking over another ("colonialization" in Habermas's terms). At least, this is the basic model. There can be more complicated versions. For example, one part of one sphere (capitalism as part of the system for Habermas) negatively affects the functional role of one part of the other sphere (say democratic will-formation in the lifeworld) - consider how, for example, wealth can come to play a problematic role in democratic will-formation through campaign donations and lobbying (this would be an example of a social pathology that is an injustice for Habermas).

Leaving aside the details here, one important question is: "Does understanding society in terms of functional differentiation problematically constrain the conceptualization of social pathology?" Here is one reason why one might think that the answer is positive. In understanding society in these terms, one, at least implicitly, tends to accept that the social world is well-constituted in principle. What needs to happen is to (re)instate how the social body functions if all of its "organs" (the different spheres) are allowed to make their contributions uninhibited by the other "organs". This approach seems apt to capture certain social problems, like the ones alluded to in the examples above, and should be part of the repertoire of FSCT. However, validating the claims about functional differentiation is a difficult business, especially if the specific claims are meant to be not just descriptive of a particular historical constellation, but have normative weight, such that were society to be differentiated into different spheres or none at all, we could meaningfully speak of a loss. It is not clear that one needs such a complex model in order to oppose, say, a right-libertarian 
approach to campaign finance and lobbying, given that liberal theories can also oppose such an approach. More importantly for the FSCT tradition, this way of conceptualizing and modelling the issues inherently tends to reformism (although it need not necessarily lead there). To see this, consider, first, a general point: models and metaphors are not innocent, neutral devices; they frame our thinking, our choice of examples, our priorities. The model of functional differentiation, basically, thinks of FSCT as an instrument for repairing and correcting something that is in principle healthy. That is to foreclose from the start the possibility that not the interaction of the "organs" of the social body are problematic, but the social body itself; that it needs replacement or radical transformation, rather than repair. Not just is capitalism downgraded by Honneth and Habermas to one among other possible causes of social pathologies, but the very idea of social pathology is understood, for the most part, in a way that removes its more radical potential. The idea that the current society is itself a pathological case of a society, not just one that is basically healthy but befallen by an illness, is being dropped (or at least made harder to think and imagine). This blunts the critical power and potential of the idea of social pathology for FSCT.

To return to an example somewhat neglected by this tradition, climate change, it is important to keep open the possibility that our capitalist societies are dysfunctional, not just in the sense of neoliberal interests's being too dominant in political decision-making, but also in the sense that those societies as a whole are endangering human survival (and that of other species and the earth's eco-system). This makes them deficient in rationality and pathological qua social formation. Perhaps this is part of what Adorno meant when he wrote:

The preservation of humanity is inexorably inscribed within the meaning of rationality: it has its end in a reasonable organization of society, otherwise it would bring its own movement to an authoritarian standstill. Humanity is organized rationally solely to the extent that it preserves its societalized subjects according to their unfettered 
potentialities. (Adorno 1998: 272-3)

In this section, I presented three specifications Honneth identifies as distinctive of (early) FSCT. I also sketched subsequent developments in Habermas and Honneth, and warned that they erode the distinctiveness and radical potential of the FSCT approach. This raises the following question: "What would it take to preserve both the distinctiveness of the FSCT conception of social pathology (vis-à-vis the dominant justice framework) and its radical potential?" In this section, I began to answer this question by suggesting that we should not make the functional differentiation of society an integral part of the conception of social pathology. In the remainder of this Chapter, I continue to answer this question with the help of two case studies and, in the process, unpack the idea of social pathology further (and what defending it would entail).

\section{Sick normality}

A search of Adorno's Collected Works does not yield one explicit mention of "social pathology," but the idea is present nonetheless. Perhaps the most vivid way it is present is in one of the mini-essays of Minima Moralia: No. 36, called "Health unto Death," dated 1944. Here Adorno states:

If such a thing as a psycho-analysis of today's prototypical culture were possible; [...] such an investigation would have to show that the sickness proper to the time consists precisely in normality. The libidinal achievements demanded of an individual behaving as healthy in body and mind, are such as can be performed only at the cost of the profoundest mutilation [...] No science has yet explored the inferno in which were forged the deformations that later emerge to daylight as cheerfulness, openness, sociability, successful adaptation to the inevitable, an equable, practical frame of mind. 
[...] The very people who burst with proofs of exuberant vitality could easily be taken for prepared corpses, from whom the news of their non-quite-successful decease has been withheld for reasons of population policy. [...] And how comfortless is the thought that the sickness of the normal does not necessarily imply as its opposite the health of the sick, but that the latter usually only present, in a different way, the same disastrous pattern. (Adorno 2005: 58-9)

The claim here is that what society considers normal and healthy comes at such high costs to individuals ("profoundest mutilation", "deformations") that it is, actually, pathological and sick. Implicit in this is a claim about society as a whole: a society which demands a sick normality of its members is itself dysfunctional, "damaged". Here we have then a clear example of a radical critique of the social body: the "disease" is not conceptualized as a misaligned relation between otherwise healthy organs, but as pertaining to the social body as a whole.

This (purported) social pathology is, however, difficult to detect. Adorno suggests that there is a double layer of repression at work:

The regular guy, the popular girl have to repress not only their desires and insights, but even the symptoms that in bourgeois times resulted from repression. (Adorno 2005: $58)$.

While the sickness of normality is concealed, this does not mean it does not exist; nor does it alter the fact that damaged society is its cause. What it does mean is that to detect it, one needs to take a perspective on society as a whole. Thus, although what Adorno presents here is a double claim about how society makes individuals ill and thereby is ill itself, he goes on to say that the social pathology cannot be detected by looking at individuals as atomistic entities:

For socially ordained sacrifice is indeed so universal as to be manifest only in society as a whole, not in the individual. Society has, as it were, assumed the sickness of all individuals. (Adorno 2005: 59) 
In one sense, this claim, for all its rhetorical starkness typical of Adorno's writings, is unsurprising. Only if a phenomenon reaches a certain threshold does it fall into the purview of sociology and social theory. For example, an isolated suicide does not demand an explanation at the (macro-)social level, but if such cases start to accumulate, then what is called for is an explanation that does not look merely at the individuals and their immediate surroundings. Even if each suicide seems unconnected to the others, at a certain level of prevalence, it makes sense to look at the broader social context. It might be difficult to know and agree what level of prevalence triggers the need for a sociological explanation, but the point holds nonetheless. In that sense, any social pathology is manifest "only in society as a whole". Adorno's thesis might be more radical than other claims about social pathology - saying not only that society produces higher levels of sickness (say depression) than there need be, but that the socially induced sickness is "universal" - but the claim that social pathologies are only visible if we look at society as a whole is not out of the ordinary.

This brings out another general point about the social pathology framework, and allows me to highlight an important challenge for using it legitimately. Thatcher, the neo-liberal UK Prime Minister from 1979-1990, famously claimed that there is no such thing as society. Theorists availing themselves of the idea of social pathology must disagree. They are inescapably committed to macro-social entities. (I understand "entities" here in a broad sense to include structures, institutions, and processes. Consumer culture is an example of "entity" in my sense.). The commitment to macro-social entities is most clearly the case in claims about how society itself is ill, but also holds in the case of claims about how society makes individuals ill. To see this, consider that a claim about the social causes of illness becomes really only a claim about social pathology when macro-social entities are invoked. For example, hardly anyone would deny that social factors are part of the causal nexus of depression. Psychiatrists often speak of "life events" as causally relevant factor. Yet, this does not make them social 
pathology theorists. For one thing, the psychiatrists need not, and typically do not, make claims about social patterns of such life events. At the point when a theorist claims that it is, say, the capitalist organization of society that produces recognisable patterns of stressful life events that lead to depression, we face a social pathology claim. Yet, invoking these macro-social entities is not just opposed by neo-liberal politicians like Thatcher, but also controversial among social scientists and philosophers. Indeed, what is even more controversial is the idea that we can treat such entities as if they were physical bodies that can be diseased (i.e., treat them as if they were organisms).

What then could vindicate invoking macro-social entities as causal factors and/or sites of illness? While this is not always explicit, the main answer is that invoking them yields explanatory surplus and success in relation to social phenomena (be it prevalence levels of depression or the rise of right-wing populism). This is not the place to establish whether, for example, Adorno's claim about sick normality is vindicated in this way. Instead, I merely want to highlight two points. The first is again about the distinctiveness of the social pathology framework vis-à-vis the justice framework. Insofar as the main vindication is by way of explanatory success of social phenomena, the social pathology framework cannot operate with the division of labour typical of the justice framework, whereby normative theorising and empirical social studies are largely separated from each other. While Rawls leaves the truth of the trickle-down theory of wealth to the economists and aims to devise principles of justice that hold either way (notably, in this context, his famous "difference principle"), Adorno could never do so. For better or for worse, the social pathology framework is intimately intertwined with social theorising and empirical research. The interdisciplinary approach of the early Frankfurt School is, thus, not accidental to the theoretical enterprise, but crucial to it.

Second, it is worth noting that postulating macro-social entities as causal factors or even as organism-like bodies might be vindicated in a structurally or even methodologically similar 
way to how the natural sciences vindicate their entities. It is also worth recalling that the latter entities, from quarks to giant black holes, seem no little strange themselves. This is not to say that philosophy or social science should become like natural science - to say that they should become so would run counter to what theorists in the FSCT tradition believe. Rather, it is to point out that philosophical or social theories should not be held to higher standards when it comes to ontology than the natural sciences. Proving causal claims, not just correlations, is a genuinely difficult endeavour. Even the supposed gold standard of such proofs, randomized control trials (RCTs), have limitations, both in whether they meet the exacting standards they require to be valid and how their results transfer across contexts (see, for example, Cartwright and Hardie 2012). Moreover, some social scientists have embarked on showing that sociological studies can meet the benchmark set by RCTs by way of what is called "natural" or "quasi-natural experiments" (Dunning 2012). (These involve an as-if-randomized distribution of individuals across groups, whereby the distribution does not arise because of an experimental set-up, but, for example, as an unintended side-effect of a policy's commencing on a certain date, such that some individuals are affected by the change and others are not.) Similarly, the ontological claims made by nuclear physicists result from certain models and their explanatory success. For example, quarks with their peculiar nature are postulated as among the fundamental elements making up reality because this makes sense of certain phenomena (whether in the artificial context of experiments or outside of it). Is it any more problematic to speak of quarks as "coloured" and "flavoured" than of society as "sick"? Both claims might be strange or perhaps metaphorical, but if they are part of successful explanatory models, then they are as vindicated as they can and need to be. In other words, the focus should not be on the ontological strangeness of certain invoked entities within a social theory, but on its overall explanatory success or lack thereof as compared to other theories. 


\section{Organized self-realization}

Earlier I criticized Honneth's reconceptualization of the idea of social pathology, especially in his later writings. However, I think there is much to learn from his discussion of specific social pathologies, especially from the middle period of his writings, where the possibility of radical critique was still left open. Here I focus on one case because I think it is particularly fruitful both in itself and in what it tells us about social pathologies and their role in FSCT.

In "Organized Self-Realization: Paradoxes of Individualization”, Honneth discusses as social pathology a process by which a genuinely worthy ideal (self-realization) becomes coopted into the reproduction of capitalist society in such a way that, paradoxically, its realization is at the same its betrayal. In a nutshell, a combination of various social factors since the 1970s have led to self-realization's being co-opted into the capitalist production process, such that people have to feign self-realization activities to become employed, to stay employed, or get promoted. As a result, people end up experiencing feelings of inner emptiness and meaninglessness (as indicated by (purportedly) rising levels of depression). Parts of the day and of the self not previously subject to direct capitalist control have been opened up to such control. Non-working time was never free under capitalism because such time was always part of a context of domination, but now this domination has seeped ever more directly into this domain. For example, it is not enough to study for a degree to secure a livelihood, one also has to orientate one's "extra-curricular" activities around the imperative of employability. Even where working times and hierarchies have become more fluid than before, this has not led simply to a progressive result, as employers are now expected to be on call and responsive 24/7. It is not enough to do a job, but one must do it enthusiastically and act as if the job is part of one's self-realization. Instead of genuine self-realization what we have is a travesty. The rhetoric of self-realization becomes part of a renewal of the capitalist production process and social world. But it is not just the rhetoric that is co-opted. Self-realization, indeed, finds 
expression in practices and actions, but merely as outwardly performance, from which the individual is alienated, such that it does not make sense to speak of genuine self-realization. What was a battle cry for emancipation and criterion for social critique has become an instrument of domination, inverting its normative valence.

Here too we see the entwinement with the social sciences (notably the work by Chiapello and Boltanski on "the new spirit of capitalism", and by Ehrenberg on the "age of depression"). We also see the process character of social pathologies: it is not that Honneth (or the theorists on whom he draws) would claim that there was a conspiracy of powerful men (and women) who decided to co-opt self-realization to renew capitalism and expand it into even further spheres of life. Rather, what he offers is an account how a reasonable response to capitalism, social critique fuelled by the value of self-realization, gets progressively taken up in social practices and thereby becomes, inadvertently and without anyone's controlling this, subverted and co-opted. (One need only think of Don Draper in Mad Men, and how he is inspired and fascinated by a series of countercultural developments and then uses them to create a new allure for mass consumer goods. It is not that Draper is in cahoots with an all-powerful elite that consciously steers US society. The mechanisms are much subtler and unfold behind the backs of all of the actors. At most, one could say that Draper wants to be good at his job insofar as he wants to find the most convincing ad for the product in question, even if this means going against the clients' initial opposition; and, more often than not, it is just accidental that the counterculture he encounters spills over into successful ads as a result of the dysfunctionality of his own life, rather than being planned as part of a conspiracy by the elites.) It is also clear from this that whatever goes wrong here is primarily ethical in nature. Insofar as a distinction of morality and ethics is drawn, self-realization is counted on the side of ethics. It is not clear what rights - legal or moral - are violated. And even structural injustice does not seem well-equipped to capture what is at issue. In addition, the way Honneth describes the 
phenomenon in question does not rely on his model of functional differentiation of society or curtail radical critique.

Moreover, while this (purported) social pathology exemplifies well some of the characteristics and specifications of social pathology highlighted already, it resists fitting into an influential schema suggested to capture the idea of social pathology in the FSCT tradition. According to Zurn, social pathologies (or at least those analysed by Honneth) are second-order disorders, where this means that they operate "by means of constitutive disconnects between first-order contents and second-order reflexive comprehension of those contents, where those disconnects are pervasive and socially caused" (2011: 345-6). Zurn's schema fits best (his characterization of) Marx's articulation of a theory of ideology: those subject to false consciousness are not "cognisant of how those beliefs come about", and this disconnect is pervasive and socially caused, involving "hiding or repressing the needed reflexivity of the social participants about the structures of belief formation and the connection of those culturalcognitive structures to the material ordering of the social world." (2011: 347) Yet, when it comes to the real target for this schema, including crucially capturing organized self-realization as social pathology, it is a poor fit. As one's own mode of self-realization requires reflective endorsement to be authentic, one could imagine a case where such second-order reflexivity is undermined by social processes. However, the way the actual phenomena is described (including by Zurn) is such that the pathology becomes worse by a cognitive connect: it is "often itself vitiated by the individual's own recognition that the demand for individualised self-realisation is itself a productive force, a functionally useful innovation of post-Fordist capitalism, one playing an ideological role in furthering neo-liberal deinstitutionalisation and deregulation." (2011: 360) If cognitive disconnect is essential to social pathology, the recognition noted in the quotation could not vitiate the social pathology, but would end it whatever would be bad about it could not be characterized in terms of Zurn's schema of social 
pathology. Put differently, Honneth does not argue that organized self-reflection is (or indicates) a social pathology because individual reflection on the ideals of self-realization pursued is blocked. Just the opposite: Honneth's argument relies on people's awareness of the false (or at least not authentically accepted) first-order content (the modes of self-realization). In fact, for him, this awareness is not just a "vitiating" factor, but part and parcel of the pathology in question - leaving us either to feign authenticity or flee into depression (2012: 167). In this way, his interesting suggestion is that social pathology can consist in the process by which the pursuit of an ideal (here self-realization) becomes co-opted and subverted, sabotaging its genuine realization.

One lesson from this is that it might not be possible (or advisable) to systematize the idea of social pathology completely. It might be better to think of it as a kind of cluster concept, with partially overlapping features, than to press it into a rigid schema. One can then take certain social phenomena (such as organized self-realization or the rise of anti-Semitism and xenophobia) as core examples of the idea. These examples constitute the idea in its diversity. The task of FSCT would then be to assemble and work through a range of such examples.

In this context, it is helpful to return to Honneth's reconceptualization of the idea of social pathology. As seen, he proposed to move away from capitalism as the ultimate cause of all social pathologies. Indeed, he seems to oppose any mono-causal picture. For example, regarding organized self-realization, he speaks of "a series of socio-structural processes of development", how they "operated in conjunction", and were "accompanied" by "cultural transformations and attitude changes." (Honneth 2012: 158f) What we get here is a complex causal nexus, in which capitalism plays a role, but is not the one and only cause. Moving away from a mono-causal picture has the advantage of increased plausibility. Still, the challenge of how to vindicate social pathology claims remains in different form. If the causal nexus is so complex and multifaceted, how can we validate the claims in question? To take one example, 
Honneth links self-realization's becoming “an ideology and a productive force in a deregulated economic system" to "a rapid rise in depression" (2012: 165). He refers to Ehrenberg's work, but he does not note the numerous controversies at stake, both about Ehrenberg's work and about the general issue. Controversies extend to (a) how depression is classified and diagnosed, (b) the claims that it is on the rise, and (c) the causes of any rise in prevalence and incidents that may have occurred. To validate Honneth's claim one would have to resolve all of these controversies about the so-called "age of depression" and link the results to the multifaceted developments in the socio-structural processes, cultural transformations and attitudinal changes that Honneth thinks are the causal nexus of "organized self-realization". That is a tough ask. Honneth is largely silent on how it might be completed. This is not just an issue for him. Zurn is probably correct to observe that of the four tasks involved in a social pathology diagnosis (symptomatology, epidemiology, aetiology, and prognosis and therapy) the third, aetiology (the study of the causes), is particularly neglected (2011: section 2). There is a lack of substantive sociological details in Honneth and Adorno alike when it comes to convincing explanations of causes.

What this also brings out is that those working in the FSCT tradition will have to turn their attention more to the second-order question of how one can validate social pathology claims. Renewed attention to philosophy of social science and a reintegration with the social sciences are called for.

\section{Conclusion}

In this Chapter, I have outlined the idea of social pathology and its role(s) in FSCT. Noting the contested nature of this idea, I proposed two key general characteristics of it: social pathologies tend to concern (a) social processes of increasing deterioration, whereby (b) deterioration is understood in ethical terms (such as self-realization and flourishing or the lack thereof) and 
contrasted to moral terms (notably justice). Following Honneth 2008, I then explicated (early) FSCT's specification of this idea as involving three elements: (c) social pathologies are understood as rationality deficits of society on a broadly Hegelian notion of reason; (d) their ultimate cause is capitalism; and (e) they include or give rise to human suffering, which fuels an emancipatory interest to overcome them. While these specifications may not suffice to distinguish FSCT from all other approaches to social and political philosophy, they, together with the general characteristics (a) and (b), differentiate it from the justice framework dominating liberal political philosophy in the last half century. This differentiation is, however, in danger (although not automatically lost) whenever theorists in the FSCT tradition reconceptualize the idea of social pathology in terms of justice. I also noted that Honneth and other theorists in the FSCT tradition have modified the later three specifications, especially (d), moving away from a mono-causal account of the genesis of social pathologies. In Habermas and Honneth, one additional, also broadly Hegelian element is introduced: (f) functional differentiation of society into spheres, whereby social pathology becomes understood as malfunctioning spheres (malfunctioning either internally or in their interactions, notably by one colonizing the other). I warned that this specification tends to restrict prematurely social critique to reforming the social body. For the social body is here understood as well-constituted in principle, and merely deviating from its healthy state. With the help of two case studies, I then suggested how the idea of social pathology could be used in ways that leave open a more radical path of social critique. And I explicated some additional general characteristics of social pathology claims and of the challenges involved in vindicating them. Specifically, social pathology claims involve (g) a commitment to macro-social entities (like society, capitalism, or consumer culture) as explanatory categories. Vindication of these commitments and the explanations to which they belong remains elusive, particularly when it comes to the claims about the causal nexus of social pathologies. There are additional challenges on which I have 
only touched briefly, notably the historical abuse of the idea of social pathology, and how using the idea seems to view theorists as social doctors and others as mere patients.

In sum, the idea of social pathology promises to be a distinctive resource for FSCT, but making good on this promise will require further work. Some of its general characteristics (such as (b) its being captured in an ethical normative register) and FSCT specifications (such as (d) the causal link to capitalism or (f) tying it to functional differentiation of society) may have to be given up or modified. And wielding it successfully, will require making good also on the interdisciplinary program of the early FSCT and on a worked-out philosophy of (social) science as well as a self-critical examination of its historical and possible uses.

\section{Further Reading}

- Honneth, A. (2008) "Critical Theory," in D. Moran (ed.), The Routledge Companion to Twentieth Century Philosophy, London/New York: Routledge, Ch. 18. (The seminal paper on the idea of social pathology in (early) FSCT.)

- Honneth, A. (2014) “The Diseases of Society: Approaching a Nearly Impossible Subject," Social Research: An International Quarterly 81(3): 683-703. (Honneth's most recent and most direct engagement with the idea of social pathology.)

- Freyenhagen, F. (2015) "Honneth on Social Pathologies: a critique," Critical Horizons 16(2): 131-52. (A critical discussion of Honneth's influential view and how it has developed from his earlier to his latest works.)

- Stuckler, D. and Basu, S. (2013) The Body Economic, London: Penguin. (Not in the FSCT tradition, but a good example of how contemporary social scientists argue that society makes us ill and is ill itself.)

- Jaeggi, R. (2014) Kritik von Lebensformen, Frankfurt a.M.: Suhrkamp Verlag. Forthcoming English translation: Critique of Forms of Life, Cambridge, MA: Harvard University Press. (Detailed account of how society and human practices embody reason and how social critique is possible within this account, including radical critique.) 


\section{References}

Adorno, T.W. (2005) Minima Moralia, translation by E.F.N. Jephcott, London: Verso. Originally in German [1951].

----- (1998) Critical Models, trans. by H.W. Pickford, New York: Columbia University Press

Cartwright, N. and Hardie, J. (2012). Evidence-Based Policy. Oxford: Oxford University Press.

Finlayson, L. (2015) The Political is Political, London: Rowman \& Littlefield International.

Foa, R.S. and Mounk, Y. (2016) “The Danger of Deconsolidation: The Democratic Disconnect," Journal of Democracy, 27(3): 5-17.

Freyenhagen, F. and O’Shea, T. (2013) “Hidden Substance: mental disorder as a challenge to normatively neutral accounts of autonomy," International Journal of Law in Context 9(1): 53-70.

Geuss, R. (2008) Philosophy and Real Politics, Princeton, NJ: Princeton University Press.

Habermas, J. (1987) The Theory of Communicative Action, Vol. II: Lifeworld and System, translated by T. McCarthy. Boston: Beacon. Originally in German [1981].

Honneth, A. (2008) “Critical Theory," in D. Moran (ed.), The Routledge Companion to Twentieth Century Philosophy, London/New York: Routledge, Ch. 18. Originally in German [2004].

----- (2012) “Organized Self-Realization: Paradoxes of Individualization,” in A. Honneth, The I in We, translated by J. Ganahl, Cambridge: Polity, Ch. 9. Originally in German [2002].

----- (2014) Freedom's Right: The Social Foundations of Democratic Life, translated by J. Ganahl, Cambridge: Polity Press. Originally in in German [2011].

Horkheimer, M. (1972) Critical Theory: Selected Essays, trans. M. J. O’Connell, New York: Herder and Herder.

Dunning T. (2012) Natural experiments in the social sciences. Cambridge: Cambridge University Press.

Stuckler, D. and Basu, S. (2013) The Body Economic, London: Penguin.

Wilkinson, R. and Pickett, K. (2009) The Spirit Level: Why Equality is Better for Everyone, London: Allen Lane.

Zurn, C.F. (2011) "Social Pathologies as Second-Order Disorders," in Petherbridge (ed.) Axel Honneth: Critical Essays, Leiden: Brill Academic Publishers, Ch. 12.

Acknowledgements: for helpful suggestions and critical discussion, I am thankful to Lorna Finlayson, Timo Jütten, Wayne Martin, Jan Overwijk, and Jörg Schaub. 